\title{
Genetic diversity in rosewood saplings (Aniba rosaeodora ducke, Lauraceae): an ecological approach
}

\author{
Ronaldo Pereira SANTOS ${ }^{1}$, Wilson Roberto SPIRONELLO², Paulo de Tarso Barbosa SAMPAIO ${ }^{3}$
}

\begin{abstract}
This article takes an ecological approach to the genetic diversity of Rosewood (Aniba rosaeodora Ducke) in a central Amazonian terra firme forest north of Manaus. Planted Rosewood setting, under partial shaded canopy, were assessed in terms of fruiting production, frugivory, and seed dispersal. Using RAPD molecular analysis procedures, the influence of the spatial distribution of adult trees on the genetic diversity (polymorphism) of saplings was assessed with genetic samples from 34 reproductive trees and 60 saplings. The density and distribution patterns the reproductive trees did not modify the sapling's diversity $(1.86 \%$, AMOVA). Two types of adult tree dispersion were identified; i) clumped and ii) more widely dispersed. Polymorphism (77.5\%) and gene flow were high between these. Although more sapling genetic variability in areas with a higher density of mature plants was not as high as expected, density did not affect the genetic diversity of samplings, indicating a high incidence of gene flow amongst trees. In planted Rosewood population (surrounded by low disturbed forest), fruiting trees experienced a high level of removal of seeds by toucans (Rhamphastidae), about of $50 \%$. The high gene flow found among native trees suggested that toucans, promoting seed rain at short and long distances from maternal trees, actively contribute to the maintenance of genetic diversity within wild rosewood populations.
\end{abstract}

KEY WORDS: Amazonian tree, RAPD, seed dispersal, gene flow, genetic diversity.

\section{Diversidade genética em plantas jovens de Pau-rosa (Aniba Rosaeodora Ducke, Lauraceae): uma abordagem ecológica}

\begin{abstract}
RESUMO
Dados genéticos e ecológicos foram obtidos do Pau-rosa (Aniba rosaeodora Ducke) em uma floresta de terra firme localizada ao norte de Manaus. Em um sistema de plantio composto de plantas sob sombreamento parcial, foram analisados dados de frugivoria, produção de frutos e dispersão. Numa população natural, com 34 plantas adultas e 60 jovens, foi analisada a influência da distribuição espacial das plantas adultas na diversidade genética (polimorfismo) das jovens utilizando o marcador molecular RAPD. O modelo de distribuição e densidade das plantas adultas não alterou a diversidade genética da progênie $(1,86 \%$; AMOVA). Tanto o polimorfismo (77,5\%) quanto o fluxo gênico entre os dois subgrupos de plantas (dispersas e agrupadas) foram altos. Embora se esperasse que a diversidade genética fosse maior na progênie oriunda do grupo com maior densidade de plantas, isso não foi observado, indicando um alto fluxo gênico entre as adultas. No plantio, as árvores com frutos tiveram uma alta taxa de remoção de sementes por tucanos (Rhamphastidae), em torno de $50 \%$. Estes resultados indicam que estes pássaros também têm um papel fundamental na dispersão de sementes em população naturais. De fato o alto fluxo gênico encontrado entre as plantas adultas em populações naturais sugere que estes animais promovem chuva de sementes a curtas e longas distâncias entre árvores reprodutivas, o que contribui com a manutenção da diversidade genética da população.
\end{abstract}

PALAVRAS-CHAVES: Árvore amazônica, RAPD, dispersão de sementes, fluxo gênico, diversidade genética.

\footnotetext{
1 Instituto Nacional de Pesquisas da Amazônia - CPST. Curso de Pós-graduação em Ciências de Florestas Tropicais. Ex-bolsitas do Programa Internacional de Pós-graduação da Fundação Ford.Manaus, AM.

2 Pesquisador do INPA - CPST. Manaus, AM.

3 Pesquisador do INPA - CPST. Manaus, AM.
} 


\section{INTRODUCTION}

The Amazonian forests compromise a huge area with a great number of habitats and, in consequence, they contain a high portion of neotropics' tree species. They are thus a rich bank of genes and diversity (Gentry, 1992). In fact, Amazonian tree species exhibit higher levels of genetic diversity than almost any other group of plants (Hamrick et al., 1992). The spatial distribution of genetic variation, i.e. within and between populations, however, varies depending on the species. Among the main factors contributing to these differences are reproductive biology, mating and crossing system, and seed dispersal agents (Epperson, 1992; Campbell \& Peart, 2001).

Within this suite of factors, gene flow promoted by long-distance dispersal agents, such as frugivores and pollinators (Bossart \& Prowell, 1998; Soons \& Ozinga, 2005; Trakhtenbrot et al., 2005) may be a powerful factor influencing observed patterns of genetic diversity. Despite the fact that many studies have focused on gene flow, questions still remain regarding the effects of pollination and seed dispersal agents on seedling survival and plant genetic diversity (Willson \& Traveset, 2000; Levine \& Murell, 2003). Studies combining classical seed dispersal methods with recently developed genetic study may lead to a more nuanced understanding of the process and consequences of gene flow.

Molecular markers are important tools for estimating levels of gene flow and this information correlates with seed dispersal distances and distribution of the genetic diversity in the plant population (Bossart \& Prowell, 1998; Ouborg et al., 1999; Cain et al., 2000). Many types of molecular markers have been used extensively for estimating gene flow rates, inferring paternity, estimating seed dispersal distances, as well as pollination rates, seed dispersal and genetic variability (Ouborg et al., 1999; Godoy \& Jordano, 2001; Kenta et al., 2004). Though their low reproducibility and dominance when compared to microsatellite markers, may present some technical difficulties, Randomly Amplified Polymorphic DNA (RAPD) markers can provide an important tool for assessing seed dispersal and gene flow, if used with their known limitations taken into consideration (Pérez et al., 1998; Ouborg et al., 1999).

Estimates of gene flow via seeds are still scarce and they seem to be inconsistent. Ecological evidence indicates that the species are dispersed particularly by animal vectors (Hamrick $\&$ Nason, 2000). Few studies have looked at the role of seed dispersal and gene flow interactions in the context of genetic diversity in native plant populations. This is particularly true for Amazonian tree species, such as Rosewood (Aniba rosaeodora).

Rosewood has long been exploited for linalool, a product used as a fixative by the perfume industry. As a result, its population has decreased to the point where the species is at risk of extinction (IBAMA, 1992). Nonetheless, high RAPD diversity in exploited natural populations of Rosewood was showed recently by Santos et al. (2008). Has the low population densities of Rosewood in exploited forests have resulted in reduced seed set? If so, we would predict that the pattern of distribution and density of remaining reproductive trees will modify the patterns of genetic diversity shown by saplings in these areas. These limitations highlight the importance of studies focusing on the ecology of seed dispersal and seedling recruitment, and how they correlate with gene flow.

The aims of this study were as follows: (i) estimate levels of natural molecular polymorphism in Rosewood saplings using molecular markers (RAPD); (ii) verify the influence of clumped and wider distributed groups of reproductive Rosewood trees on saplings' genetic diversity; (iii) measure the rates of seed removal from planted trees under partial shaded terra firme forest; and (iv) integrated molecular markers (RAPD) and ecological procedures data for better understanding Rosewood's ecology and management.

\section{MATERIALS AND METHODS}

\section{STUDY SITE}

The study site is located in the Aldopho Ducke Forest Reserve $\left(100 \mathrm{~km}^{2}\right), 26 \mathrm{~km}$ north of Manaus in central Amazonia ( $\left.2^{\circ} 37^{\prime} \mathrm{S}, 60^{\circ} 11^{\prime} \mathrm{W}\right)$. The area has undergone some human perturbation as a consequence of selective logging, hunting, and forestry experiments. However, the vegetative structure and the animal communities have been little modified overall (Ribeiro et al., 1999).

The climate is of the Afi type, with average annual rainfall of $2400 \mathrm{~mm}$, ranging from $100 \mathrm{~mm}$ in July to $300 \mathrm{~mm}$ in April. The rainy season extends from December to May, and the dry season from June to November. According to Thornthwaite's water balance, a water deficit occurs in the soil between the months of August and October (Ribeiro \& Villa Nova, 1979). The relief is composed of rolling hills, with a variation of altitude of $100 \mathrm{~m}$ between the plateaus and the lowlands. The vegetation in this area is known as terra firme tropical rainforest with a predominance of small streams (Prance, 1990). The structure and the floristic composition of this formation are defined mainly by the type of soil and relief (Ribeiro et al., 1999). In the higher areas, the soil is clayey yellow latosoils and the tree canopies reach up to $30-35 \mathrm{~m}$ in height. In the lower areas, the soil is mostly sandy, and there is a predominance of Oenocarpus bataua Mart.

\section{STUDY SPECIES}

Aniba rosaeodora Ducke var. amazonica Ducke, (synonymous with Aniba duckei Kostermans) is a member 
of the Lauraceae. Widely distributed in the Amazon (Ducke, 1938), it is commonly known as Pau-rosa (Br.), Rosewood (Eng.), and Bois de Rose (Fr.).

Rosewood is important as a source of linalool, the main component of an essential oil found throughout plant (Araújo et al., 1971). In the world perfume market, linalool is extremely valuable (May \& Barata, 2004; Santos et al., 2004). Due to the predatory nature of the most commonly used extraction practices, access to the areas with remaining economically exploitable populations is extremely difficult because the remaining areas are few and geographically inaccessible (SUDAM, 1972; May \& Barata, 2004). Consequently, the species was included in the national threatened species' list (IBAMA, 1992).

Rosewood grows in yellow and red latosols, both in clay and sandy clay, almost entirely in never-flooded terra firme forests; plants reach $30 \mathrm{~m}$ in height (Alencar \& Fernandes, 1978; Loureiro et al., 1979). Flowers are bisexual with
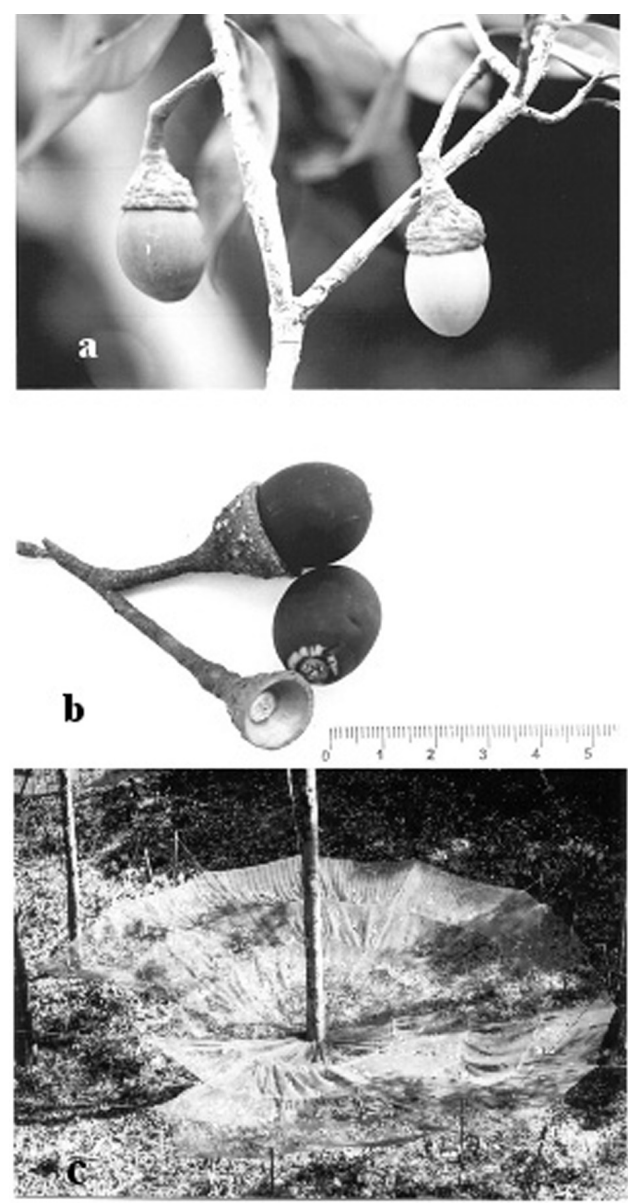

Figure 1 - a,b) Fruits of the Aniba rosaeodora showing three phases: unripe (light gray, a); intermediate (dark gray, a) and ripe (b). The cupule, a characteristic of the family Lauraceae is also shown (b); c) fruit production for each individual tree was quantified using fruit trap sewn in circles to cover the full projection of the tree canopy. (Photo: Wilson R. Spironello). temporal dioecy (Kubitzki \& Renner, 1982; Kubitzki \& Kurz, 1984). The fruit is a drupe, purple in color, $26,5 \times 19,5 \mathrm{~mm}$ in size; with a typical Lauraceous cupule at the base (see Fig. $1 \mathrm{a}-\mathrm{c})$

\section{FRUIT PRODUCTION, FRUGIVORY AND SEED DISPERSAL}

The study focused on planted trees under partial shaded terra firme forest area (1-ha plot (Alencar \& Fernandes, 1978), since native Rosewood population did not fruit during the study period (2000/2002).

Ten fruiting trees were randomly selected $(n=85$ reproductive individual) and fruit production for each individual tree was quantified using fruit traps, which were made from 1-mm mesh nylon nets sewn in circles to cover the full projection of the tree canopy (see Fig. 1c). Data collection was carried out weekly during the immature phase, and daily following the beginning of fruiting. Animals consuming the fruits were identified, and their foraging behavior described, using the focal sampling method (Martin \& Bateson, 1993). The following data was recorded: (1) number of fruits consumed; (2) number of fruits discarded; (3) time the seed remained in the animal's stomach; and (4) removal distances. Removal distance was estimated by considering the time the seed remained in the animal's stomach and the distance the animal traveled during the observation period. The distances were measured using a $50 \mathrm{~m}$ measuring tape and classified as: short distance $(<50 \mathrm{~m})$ and long distance $(>50 \mathrm{~m})$. Removal of seeds from the focal tree was assessed considering only one focal daily record per fruit-consumer species, thus avoiding overestimation of those contribution species that visited fruiting trees more frequently. Afterwards the removal of seeds by frugivores was confronted with the seed removal data assessing fruit-trap method (see below) to test if the focal method was reliable.

Removal of seeds was also assessing using fruit-trap method. The total number of cupules that fell into fruit traps or which were collected in the subject tree canopies were comparable with the total number of fruits collected in the traps and the difference in numbers was therefore attributed to the category "fruits/seeds potentially dispersed". The difference between the overall focal estimate of fruits/seeds dispersed by frugivores and that obtained from fruit trap was evaluated by a $G$ test.

\section{GENE FLOW AND DIVERSITY IN ROSEWOOD SAPLINGS}

\section{Sampling and DNA isolation}

Fresh young leaves of 34 reproductive plants and 60 saplings, ranging from 10 to $60 \mathrm{~cm}$, were collected from a natural population some $5 \mathrm{~km}$ away from the plot of planted trees. Saplings were sampled within a 15-meter radius around 
the adult trees. Leaves were placed in plastic tubes with silica gel and stored at $-20^{\circ} \mathrm{C}$ at the Plant Biotechnology Laboratory of INPA (Manaus). The DNA was extracted following the procedure of Edwards et al. (1991), and its concentration was estimated using a spectrophotometer (GeneQuant device pro RNA/DNA Calculator).

RAPD reactions and visualization bands pattern

A total of nine RAPD primers (Gibco BRL) were evaluated for information content and reproducibility. Only those exhibiting $80 \%$ or more of reproducibility were scored (following Santos et al. 2007). The RAPD reactions were performed in a $25 \mu \mathrm{L}$ volume containing 30 ng of DNA, 2.5 $\mathrm{U}$ of Taq DNA polymerase, $3.0 \mathrm{mM}$ of $\mathrm{MgCl}_{2}, 500 \mathrm{nM}$ of primer, $100 \mu \mathrm{M}$ of each dNTP and BSA (0.1\%). A polymerase chain reaction (PCR) was performed in a Perkin Elmer Gene Amp PCR System 2400 thermal cycler as follows: $92^{\circ} \mathrm{C}$ for 1 min, followed by 35 cycles of $92^{\circ} \mathrm{C}$ for $1 \mathrm{~min}, 35^{\circ} \mathrm{C}$ for $2 \mathrm{~min}$ and $72^{\circ} \mathrm{C}$ for $1 \mathrm{~min}$, and a final extension cycle of $72^{\circ} \mathrm{C}$ for 5 min. The PCR products were stored at $4{ }^{\circ} \mathrm{C}$ until processing. Electrophoresis was performed on $1.5 \%$ agarose gels at $5 \mathrm{~V} /$ $\mathrm{cm}, 200$ to $250 \mathrm{~mA}$, for 3 hours using TBE 1 X buffer. Gels were stained with ethidium bromide $(0.5 \mathrm{mg} / \mathrm{ml})$, visualized under UV light and captured with the Kodak Digital Zoom Camera photo-documentation system and accessory software (Kodak Digital Science DC120 Kit Gel Documentation Accessory Kit and 1D Image Analysis Software).

\section{GENETIC AND STATISTIC ANALYSIS}

In the genetic analysis were taken in consideration two subgroups of trees, as follows: (1) clumped, $n=23$ mature plants, 2.5 trees. $\mathrm{km}^{-2}$; and (2) wider distributed, $n=11$ mature plants, 0.24 trees. $\mathrm{km}^{-2}$ (see Fig. 2). The percentage of polymorphic loci for saplings in each subgroup was calculated with POPGENE 1.32 (Yeh et al., 1999). The distribution of the genetic diversity within and between the subgroups was evaluated by Analysis of Molecular Variance (AMOVA) (Excoffier et al., 1992) with the software Arlequim 2.0 (Schneider et al., 2000). The Euclidean matrix of genetic distances was used and tested with 1000 permutations. The gene flow $(\mathrm{Nm})$ between the two subgroups was estimated following Slatkin \& Barton (1989) using POPGENE. The frequencies of RAPD markers were evaluated by Fisher's exact test (Raymond \& Rousset, 1995), using TFPGA (Miller, 1997). In order to minimize the recognized limitations of the RAPD methodology - especially with respect to transforming gel fragment frequencies into allele frequencies - we assumed each locus to be a two-allele system, with only one of the alleles per locus being amplifiable by the PCR. Hence, these frequencies were calculated with TFPGA and POPGENE software using a correction for dominance and with an awareness that RAPD fragments from different loci do not

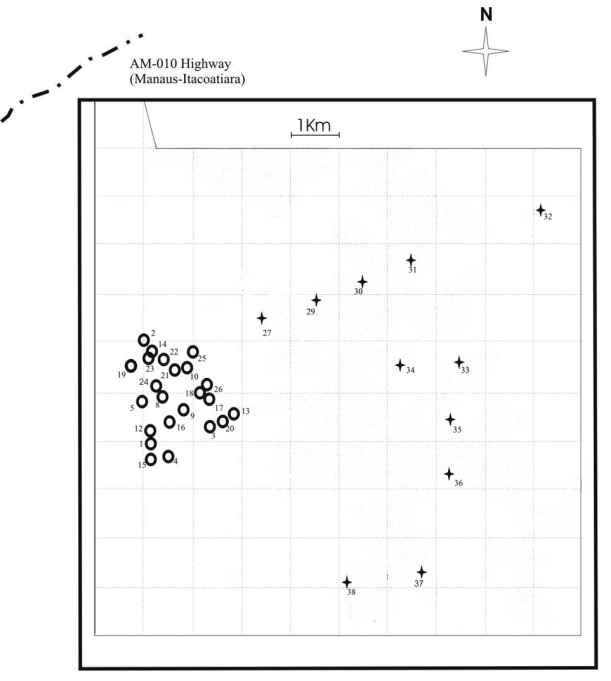

Figure 2 - Distribution of native mature Rosewood (Aniba rosaeodora Ducke) plants in Adolpho Ducke Forest Reserve (Manaus/AM, Brazil): circles represent areas with high densities of adult plants; and crosses represents plants found to be more dispersed.

co-migrate to the same place on a gel (Lynch \& Milligan 1994). An additional variable was the established fact that RAPD fragments are not necessarily genes but fragments of DNA, albeit consistently replicable ones.

\section{RESULTS}

\section{FRUIT PRODUCTION AND DURATION OF FRUITING}

Rosewood planted trees produced $408 \pm 406$ fruits, ranging from 200 to 1600 fruits (10 trees, DBH ranging 19-39 $\mathrm{cm}, n=6770$ fruits). The average time of fruit development was $419 \pm 39$ days $(\mathrm{n}=12$ trees). The average fruiting time of the planted trees was $140 \pm 22$ days, totaling six months at the population level (June to November), with a peak between July and September (dry season).

\section{FRUGIVORY AND SEED DISPERSAL}

Frugivory data were recorded between July and November 2001 , totaling 42 days of observation and up to 280 hours focal fruiting trees. Only diurnal birds were recorded consuming the pulp of Rosewood fruits in the plantation setting (70 animal focal records, $n=23$ trees): Selenidera piperivora (35 $\mathrm{cm}$ in length, see Fig. 3) and Rhamphastos tucanus $(55 \mathrm{~cm})$. The former species visited the fruiting trees more frequently, representing $74 \%$ of the records ( $1-3$ individuals), while $26 \%$ of the records were of the latter toucan (1-5 individuals). Rhamphastos made short visits, with an average stay of 5 min., ranging 2-14 min., while the smaller species remained longer on the tree, with an average stay of $27 \mathrm{~min}$., ranging 23-120 minute. There was also a difference in their utilization of the fruit, as well as in the capacity to ingest fruits, with 
Rhamphastos (2.1 $\pm 1.2 ; n=30$ fruits) exceeding Selenidera (1.1 $\pm 0.4 ; n=40$ fruits). The fate of fruits taken by toucans was analyzed by using just one of the daily focal records per species, thus avoiding overestimation of those contribution species that visited fruiting trees more frequently $(n=88$ fruits taken). Rhamphastos were more efficient in removing the fruits (84\%) compared to Selenidera (36.5\%) (Table 1). Despite of being less efficient in removal, the latter species dispersed almost the same amount of seeds (26\% of the fruits taken) as did Ramphastos (24\%). Nevertheless, the larger toucan was more efficient for long distance removal, since Selenidera remained for longer periods at and near to the foraging site. For this reason many of the seeds ingested were regurgitated $(17 \pm 5$ min., $n=5)$ under or at short distances from maternal trees $(<50 \mathrm{~m}$; Table 1$)$.

Overall focal estimates of fruits fruits/seeds dispersed by frugivores $(50 \%)$ did not differ significantly from that obtained from fruit traps $(46 \%)(G$ test $=2.11 ; d . f .=1$; $p>0.10)$. This result implies that toucans were the main consumer and dispersal agents of $A$. rosaeodora in planted Rosewood setting.

\section{DIVERSITY, SPATIAL DISTRIBUTION AND GENE FLOW BASED ON MOLECULAR MARKERS}

The RAPD fragments from samplings plants ranged in size from 0.3 to $2.0 \mathrm{~kb}$; 55 of 71 were polymorphic $(77.5 \%)$

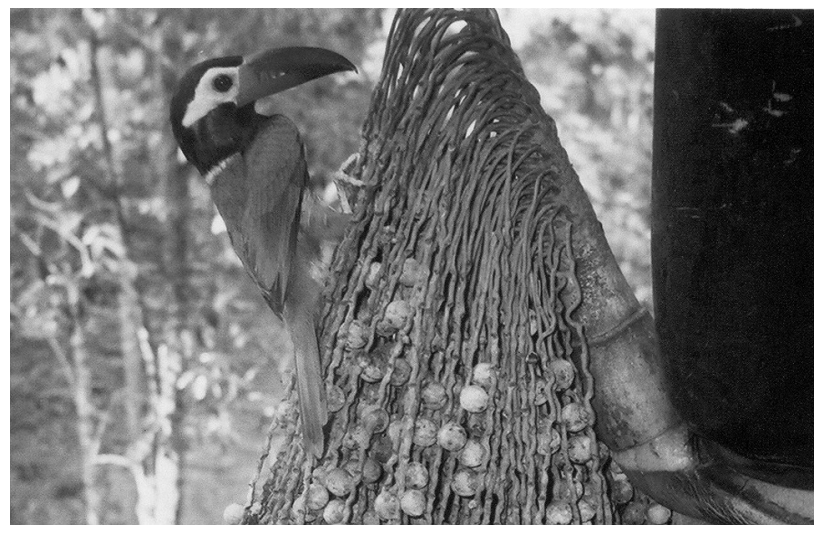

Figure 3 - Selenidera piperivora is an important fruit consumers and dispersal agent of Rosewood (Aniba rosaeodora Ducke). (Photo: Wilson R. Spironello). across the whole sample set. Levels of polymorphism were similar between the two subgroups of trees (clumped and more widely distributed). Fisher's exact test indicated the existence of no disequilibria for marker frequencies in all the comparisons between the subgroups ( $<<0.05)$.

Analysis of Molecular Variance (AMOVA) indicated that most of the genetic diversity variation is due to differences within- $(98.14 \% ; \mathrm{p}<0.025)$ rather than between-subgroups of trees. Gene flow estimate was very high between these subgroups $(\mathrm{Nm}=33.0)$.

\section{DISCUSSION}

\section{SEED-REMOVAL AGENTS OF ROSEWOOD}

The fruits of Lauraceae are large, with a single seed enveloped in pulp that is rich in lipids and carbohydrates morphological and nutritional characteristics associated with dispersal by specialized birds (McKey, 1975; Snow, 1981; Mazer \& Wheelwright, 1993). Our findings are consistent with these observations, as seeds removed from the Rosewood ex situ population, surrounded by terra firme forest, were predominantly dispersed by toucans. This result implies that these birds might also play an important role as seed dispersal agent in native Rosewood populations.

Our results showed also that toucans disperse the seeds of a large number of other plant species in the forest (up to 50 collected in fruit traps), including predominantly members of the families Annonaceae, Arecaceae, Lauraceae and Moraceae. Eliminating these important agents of dispersal might well affect the natural generation processes of plants with ornithochorous dispersal syndromes. This underscores the role of these birds in maintaining the diversity of Neotropical forests.

\section{SPATIAL DISTRIBUTION, GENE FLOW AND GENETIC DIVERSITY OF SAPLINGS}

In most tropical species, the spatial distribution of seedlings and saplings is not a random process, but it is influenced by a complex interaction of factors, e.g. seed dispersers, soil and light. It is a process that occurs in isolation, nor does it occur randomly in space, instead it exhibits a characteristic pattern. This pattern may depend on the seed rain promoting by

Table 1 - Foraging behavior and fate of the Aniba rosaeodora fruits taken by toucans: Selenidera piperivora ( $\mathrm{n}=63$ fruits) and Rhamphastos tucanus ( $\mathrm{n}=25$ fruits).

\begin{tabular}{lccccccc}
\hline & Fruit utilized and rejected & Fruit ingested & ${ }^{* *}$ Fruit removed & \multicolumn{4}{c}{ Fate of the fruits ingested and removed } \\
\cline { 2 - 8 } Species & $(\%)$ & $(\%)$ & $(\%)$ & & \multicolumn{2}{c}{$(\%)$} & \\
\cline { 2 - 8 } & & & & local & $<50 \mathrm{~m}$ & $\geq 50 \mathrm{~m}$ & Overall \\
\hline Selenidera piperivora & 49.2 & 39.7 & 11.1 & 28 & 47 & 25 & $\mathbf{2 6}$ \\
Rhamphastos tucanus & 16 & 84 & 0 & 0 & 0 & 84 & 24 \\
\hline
\end{tabular}

** Fruit removed and consumed in another local 
dispersal agents, which, in itself, contributes to the genetic structuring and overall diversity of the population (Ulft, 2004).

Many studies have assumed, under field conditions, that seeds under and/or nearby fruiting trees are their progenies (Smouse \& Sork, 2004). Although this assumption may be correct for plant species that exhibit restricted seed dispersal (Redmond et al., 1989; Godoy \& Jordano, 2001, Wenny, 2000), it needs to be applied with caution because dispersal agents, such as toucans, disperse the seeds from both neighboring fruiting trees and those at some distance away. Therefore, it is reasonable to expect that the distance and densities of adult plants will affect the distribution of diversity of saplings in the natural populations. Nonetheless, our findings suggest that the molecular diversity of Rosewood' saplings is not influenced by adult density (only 1.86\% difference between two subgroups). Besides that, polymorphism was the same in both subgroups analyzed. This might be explained either by high rates of pollen movement (not assessed) and/or by high rates of seeds movement between one subgroup and another. This is supported by very high estimate of gene flow $(\mathrm{Nm}=$ 33.0). The recognized limitations of the RAPD methodology might lead some to contest this data, nevertheless, we believe ample corrections procedures were made when evaluating marker consistency and reproducibility (Lynch \& Milligan 1994, Perez et al., 1998; Santos et al. 2007), and therefore consider that our analyses coherent and accurate explanation of the observed patterns of gene flow.

The high movement of seeds found in planted Rosewood population corroborates previous studies of the Lauraceae (such as that of Wheelwright, 1993), which also found that nearly $50 \%$ of the seeds were removed and dispersed away from maternal trees. In addition, genetic studies of Ocotea tenera (Lauraceae) have shown that there is a high gene flow between populations, and that that this is mediated primarily through seed dispersal by toucans (Gibson et al., 1996). In the current study planted Rosewood trees had a high seed removal rate, promoted by seed dispersal agents, and in native population a very high gene flow among the subgroups . This also corroborates to high RAPD diversity in natural adults populations of Rosewood (Santos et al., 2008), as well high polymorphism identified in Rosewood's microsatellites locis (Angrizani et al., 2008). These results imply that seed removals might play an important role in gene movement in native Rosewood population, but we were unable to assess its total contribution since rates of gene flow via pollen flow were not evaluated.

Reviews considering the relative importance of pollen versus seed dispersal for gene flow have concluded that pollen flow contributes more than seed dispersal to the genetic heterogeneity of tree populations (e.g., El-Mousadik \& Petit,
1996; Hamilton \& Miller, 2002). This may be a consequence of most investigations has been focusing on pollen flow while gene flows by seeds remaining poor known or underestimated (Hamrick \& Nason, 2000). Seed and pollen movement have been therefore recognized as fundamental in the maintenance and conservation of diversity in forest communities (Bossart \& Prowell, 1998; Soons \& Ozinga, 2005; Trakhtenbrot et al., 2005). This study, along with preliminary results assessing seed dispersal in native Rosewood population (unpubl. data), corroborate this, since a high numbers of seeds were dispersed away from maternal fruiting trees by birds, mainly toucans (Selinidera culik, Rhamphastos vitellinus and R. tucanus).

Although there is no consensus on the predominant mating system for Rosewood, the rate of outcrossing is suspected to be high and similar to other Lauraceae species (Gibson et al., 1996; Moraes \& Monteiro, 2002). This could further explain the high levels of genetic diversity found in this current study. Moreover, Santos (2004) found a slight but significantly higher polymorphism in seedlings and saplings than in adult plants, suggesting intense selection on early stages of development. These findings are important when considering the ecological role of the genetic variation for saplings under adverse environment conditions, as such soil fertility, shading, seed and fruit predation and pests.

\section{ACKNOWLEDGMENTS}

Research and logistic clearance were provided by the Brazilian National Institute for Amazon Research (INPA) and the Forestry Research Department (CPST). The pilot study was funded by the Brazilian Environmental Agency Foundation (FNMA) and the Ford Foundation International Fellowship Program. We thank the following people for their help with various aspects of this project: Dra. Alexandra Casa, for valuable comments, suggestions and revision of the manuscript (Cornell University, USA); and Dra. Paula Cristina Angelo, for technical and scientific advises during lab analysis carried at EMBRAPA - Manaus, Brazil. Adrian Barnett polished the English for the final version of the manuscript.

\section{LITERATURE CITED}

Angrizani, R.C.; Lemes, M.R.; Contim, L.S. 2008. Desenvolvimento e caracterização de marcadores microssatélites para Aniba rosaeodora Ducke (Lauraceae), uma espécie florestal amazônica. In. Resumos do $54^{\circ}$ Congresso Brasileiro de Genética. 16 a 19 de setembro de 2008. Salvador - BA, Brasil . pg. 26.

Alencar, J.C.; Fernandes, N.P. 1978. Desenvolvimento de árvores nativas em ensaios de espécies, Pau-rosa (Aniba duckei, Kostermans). Acta Amazônica, 8(4): 523-541. 
Araújo, V.C.; Correa, R.G.C.; Maia, J.G.S.; Silva, M.L.; Gottlieb, O.R.; Marx, M.C.; Magalhães, L.M.S. 1971. Óleos essenciais da Amazônia contendo linalol. Acta amazonica, 1(3): 45-47.

Bossart, J.L.; Prowell, D.P. 1998. Genetic estimates of population structure and gene flow: limitations, lessons, and new directions. Trends in Ecology and Evolution, 13: 202-206.

Cain, M.L.; Milligan, B.G.; Strand, A.E. 2000. Long-distance seed dispersal in plant populations. Am. J.Bot., 87(9): 1217-1227.

Campbell, O.W.; Peart D.R. 2001. High seed dispersal rates in faunally intact tropical rain forest: theoretical and conservation implications. Ecol. Lett., 4: 491-499.

Ducke, A. 1938. Lauráceas aromáticas da Amazônia brasileira. In: Reuniāo Sul-Americana de Botânica, Jardim Botânico, Rio de Janeiro. p. 55-65.

Edwards, K.; Johnstone, C.; Thompsons, C. 1991. A simple and rapid method for the preparation of plant genomic DNA for PCR analysis. Nucleic Acids Res., 19: 1349.

El-Mousadik, A.; Petit, R.J. 1996. Chloroplast DNA phylogeography of the argan tree of Morocco. Mol. Ecol., 5: 547-555.

Epperson, B.K. 1992. Spatial structure of genetic variation within populations of forest tree. New For., 6: 257-278.

Excoffier, L.; Smouse, P.E.; Quattro, J.M. 1992. Analysis of molecular variance inferred from metric distance among DNA haplotypes: application to human mitochondrial restriction data. Genetics, 131: 479-491.

Gentry, AH. 1992. Tropical forest biodiversity: distributional patterns and their conservational significance. Oikos, 63: 19-28.

Gibson, J.P.; Wheelwright, N.T.; Nathaniel, T. 1996. Mating system dynamics of Ocotea tenera (Lauraceae) a gynodioecious tropical tree. Am. J. Bot., 83(7): 890-894.

Godoy, J.A.; Jordano, P. 2001. Seed dispersal by animals: exact identification of source trees with endocarp DNA microsatellites. Mol. Ecol., 10: 2275-2283.

Hamilton, B.M.; Miller, J.R. 2002. Comparing relative rates of pollen and seed gene flow in the island model using nuclear and organelle measures of population structure. Genetics, 162: 1897-1909.

Hamrick, J.L.; Godt, M.J.W.; Sherman-Broyles, S.L. 1992. Factors influencing levels of genetic diversity in wood plant species. New For., 6: 95-124.

Hamrick, J.L.; Nason, J.D. 2000. Gene flow in forest trees. In: Young, A.; Goshier, D.; Boyle, T. (Eds). Forest Conservations genetics - Principles and practice. CSIRO Publishing, Collinwood, Australia. p. 81-90.

Ibama, 1992, $1^{\text {a }}$ Portaria № 37 de 3 de abril de 1992.

Kenta, T. Isagi, Y.; Nakagawa, M.; Yamashita, M.; Nakashizuka, T. 2004. Variation in pollen dispersal between years with different pollination conditions in a tropical emergent tree. Mol. Ecol., 13: 3575-3584.

Kubizki, K.; Kurz, H. 1984. Sincronized dichogamy and dioecy in Neotropical Lauraceae. Plant Syst. Evol., 147: 253-266.
Kubizki, K.; Renner, S. 1982. Lauraceae I (Aniba and Aiouea). Flora Neotropica, Monograph number 31. The New York Botanical Gardem. New York.

Levine, J.M.; Murrell, D.J. 2003. The community-level consequences of seed dispersal patterns. Annu. Rev. Ecol. Evol. Syst., 34: 549374.

Loureiro, A.A.; Silva, M.F.; Alencar, J.C. 1979. Essências madeireiras da Amazônia. INPA, 2 (18): 1-245.

Lynch, M.; Milligan, B.G. 1994. Analysis of population genetic structure with RAPD markers. Mol. Ecol., 3: 91-99.

Martin, P.; Bateson, P. 1993. Measuring Behavior: An Introductory Guide. Cambridge University Press, London. 222pp.

May, P.H.; Barata, L.E.S. 2004. Rosewood exploitation on Brazilian Amazon: options for sustainable production. Econ. Bot., 58 (2): 257-265.

Mazer, S.J.; Wheelwright, N.T. 1993. Fruit size and shape allometry at different taxonomic levels in bird-dispersed plants. Evol. Ecol., $7: 556-575$.

McKey, D. 1975. The ecology of coevolved seed dispersal systems. In: Gilbert, L.E.; Raven, P.H. (Eds). Coevolution of plants and animals. University of Texas Press, Austin, Texas. p. 53-77.

Miller, MP. 1997. Tools for Population Genetic Analysis (TFPGA), version 13. Northern Arizona University.

Moraes, P.L.R.; Monteiro, R. 2002. Taxas de cruzamento em uma população natural de Cryptocarya moschata Nees (Lauraceae). Biota Neotropica, 2:(2): 1-10. (http://www.biotaneotropica. cria.org.br/v2n2/pt/fullpaper?bn01102022002+pt). Acesso: $15 / 05 / 2004$.

Ouborg, N.J.; Piquot, Y.; Van Groenendael, J.M. 1999. Population genetics, molecular markers and the study of dispersal in plants. J. Ecol., 87: 551-568.

Perez, T.; Albornoz, J.; Domínguez, A. 1998. An evaluation of RAPD fragment reproducibility and nature. Mol. Ecol., 7: 1347-1357.

Prance, G.T. 1990. The floristic composition of the forests of Central Amazonian Brazil. In: Gentry, A.H. (Ed). Four Neotropical Rainforests. New Haven, Yale University Press. p. 112-140.

Raymond, M.; Rousset, F. 1995. An exact test for population differentiation. Evolution, 49: 1280-1283.

Redmond, A.; Robbins, J.; Travis, L. 1989. The effects of pollination distance on seed production in three populations of Amianthium muscaetoxicum (Liliaceae). Oecologia, 9: 260-264.

Ribeiro, J.E.L.S.; Hopkins, M.J.G.; Vicentini, A.; Sothers, C.A.; Costa, M.A.S.; Brito, J.M.; Souza, M.A.D.; Lohrman, L.G.; Assunção, P.A.C.L.; Silva, C.F.; Mesquita, M.; Rocópio, L.C. 1999. Flora da Reserva Ducke: Guia de identificação das plantas vasculares de uma floresta de terra firme na Amazônia Central Manaus. INPA - DFIP, Manaus. 793pp.

Ribeiro, M.N.G.; Villa nova, N.A. 1979. Estudos climatológicos da Reserva Florestal Ducke, Manaus, AM. III: Evapotranspiração. Acta Amazonica, 9(2): 305-309. 
Santos, A.S.; Antunes, A.M.S.; D'avila, L.A. 2004. New natural Linalol sources: research and industrial application. Perf. Flav., 29: 38-43.

Santos, R.P. 2004, Avaliação da diversidade genética de populaçôes naturais de Pau-rosa (Aniba rosaeodora Ducke) por meio de marcadores moleculares RAPD. Dissertação de Mestrado, INPAUFAM, Manaus. 81pp.

Santos, R.P.; Angelo, B.C.S.; Sampaio, P.T.B. ; Quisen, R.C.; Leite, A.M.C.; Oliveira, C.L. 2008. Geographic pattern of genetic diversity in natural populations of Rosewood (Aniba rosaeodora), in the Central Amazonia. Acta Amazonica, 38(3): 52-58.

Santos, R.P.; Angelo, P.C.S; Quisen, R.C.; Oliveira, C,L.; Sampaio, P.T.B.; Cruz, J.S. 2007. RAPD em Pau-Rosa (Aniba rosaeodora Ducke): adaptação do método para coleta de amostra in situ, ajustes nas condições de PCR e apresentação de processo para selecionar bandas representativas. Acta Amazonica, 37(2): 253260.

Schneider, S.; Roessli, D.; Excoffier L. 2000. Arlequim ver 2000: A softwere for population genetics data analysis. Genetics and Biometry Laboratory. University of Geneva, Switzerland.

Slatkin, M.; Barton, N.H. 1989. A comparison of three indirect methods for estimating average of gene flow. Evolution, 43: 1349-1346.

Smouse, P.E.; Sork, P.E. 2004. Measuring pollen flow in forest trees: an exposition of alternative approaches. Forest Ecol. Manage., 197: 21-38.

Snow, D.W. 1981 Tropical frugivorous birds and their food plants: a world survey. Biotropica, 13(1): 1-14.

Soons, M.; Ozinga, W.A. 2005. How important is long-distance seed dispersal for the regional survival of plant species? Diversity and Distributions, 11 (2): 165-172.
Sudam. 1972. O extrativismo do Pau-rosa (Aniba Duckei Kostem - A rosaeodora Ducke): Aspectos sócio-econômicos a silvicultura da espécie. SUDAM. Belém: Doc. Amaz., 3 (1/4): 5-55.

Trakhtenbrot, A.; Nathan, R.; Perry, G.; Richardson, DM. 2005. The importance of long-distance dispersal in biodiversity conservation. Diversity and Distributions, 11(2): 173-181.

Ulft, L.H. van. 2004. The determinants of the spatial distribution of tree seedlings in the tropical rain forest of central Guyana. In: Ulft, L.H. van (Ed). Regeneration in Natural and Logged Tropical Rain Forest - Modeling seed dispersal and regeneration of tropical trees in Guyana. Series 12. Tropenbos-Guyana Programme, Georgetown, Guyana. (http://www.tropenbos.nl/files/guyser12. htm). Acesso: 02/10/2005.

Wenny, D.G. 2000. Seed dispersal, seed predation, and seedling recruitment of a Neotropical montane tree. Ecological Monographs, 70(2): 331-351.

Wheelwright, N.T. 1993. Fruit size in a tropical tree species: variation preference by birds and heritability. Vegetatio, 107108: 163-174.

Willson, M.F.; Traveset, A. 2000. The ecology of seed dispersal. In: Fenner, M. (Ed). Seeds: The ecology of regeneration in plant communities. 2nd. Edition. CAB International, Wallingford, UK. p. 85-110.

Yeh, F.C.; Yang, R.C.; Boyle, T. 1999. POPGENE: Microsoft Windowbased freeware for population genetic analysis, version 1.3: Manual Edmonton: University of Alberta.

Recebido em 24/03/2007

Aceito em 28/08/2008 